\title{
STATUS NUTRISI LANSIA DAN RISIKO JATUH PADA LANSIA
}

\section{Sofia Rhosma Dewi}

(Fakultas Ilmu Kesehatan Universitas Muhammadiyah Jember

Jl. Karimata 49 Jember, email : sofiarhosma84@gmail.com)

\begin{abstract}
ABSTRAK
Malnutrisi pada lansia dapat menyebabkan gangguan fungsi otot, gangguan kognitif, penurunan massa tulang, dan peningkatan morbiditas. Gangguan fungsi otot dan penurunan massa tulang akan mempengaruhi fungsi motorik lansia yang dapat menyebabkan ketidakseimbangan fungsi postur tubuh yang menjadi salah satu prediktor jatuh pada lansia. Tujuan dari penelitian ini adalah untuk mengetahui hubungan antara status gizi lansia dan risiko jatuh di UPT PSTW Jember. Penelitian ini adalah korelasional yang dilakukan dengan pendekatan cross sectional. Ada 77 responden dalam penelitian ini dari total 140 lansia di UPT PSTW Jember. Responden diambil secara purposive sampling. Data yang diambil menggunakan MNA untuk status gizi dan TUG untuk risiko jatuh, data dianalisis dengan menggunakan uji korelasi spearman. Analisis statistik menunjukkan nilai $\mathrm{p}$ 0,081 yang berarti tidak ada korelasi yang signifikan antara status gizi lansia dan risiko jatuh. Turunnya usia lanjut dipengaruhi oleh faktorfaktor lain seperti gangguan sensorik, perubahan patologis, riwayat jatuh dan lingkungan.
\end{abstract}

Kata kunci: Lansia, Status Gizi, Jatuh

\begin{abstract}
Malnutrition in elderly could lead to impaired muslce's function, cognitive impairment, bone mass declining and increased morbidity. Impaired muscle's function and bone mass declining will affect elderly's motoric function that could lead to imbalance postural function that become one of elderly's fall predictors. The purpose of this study is to find out the correlational between elderly's nutritional status and risk of fall in UPT PSTW Jember. It's a correlational research conducted with cross sectional approach. There were 77 respondents who take a part in this study from the total 140 elderly in UPT PSTW Jember. The respondent taken by purposive sampling. The data taken by MNA for nutritional status and TUG for risk of fall the the data analysed using spearman correlation test. Statystical analysis show p value 0,081 which mean there were no significant correlation between elderly's nutritional status and risk of fall. Fall in elderly were affected by the other factors such as sensory impairment, patological changes, history of fall and environment.
\end{abstract}

Key words : Elderly, Nutritional Status, Fall 


\section{PENDAHULUAN}

Indonesia merupakan salah satu negara berkembang dengan jumlah lansia terbanyak di dunia. Indonesia diproyeksikan memasuki periode lansia pada tahun 2010 2035 dengan jumlah lansia diperkirakan mencapai 48, 2 juta jiwa pada tahun 2035 . Peningkatan jumlah lansia disebabkan oleh peningkatan usia harapan hidup penduduk Indonesia. Usia harapan hidup di Indonesia mencapai 70,8 tahun pada 2015.

Peningkatan usia harapan hidup merupakan salah satu indikator kemajuan pembangunan kesehatan di suatu negara. Namun di sisi lain peningkatan usia harapan hidup yang berdampak pada peningkatan angka ketergantungan nasional.

Pertambahan usia yang dialami lansia membawa konsekuensi terhadap penurunan fungsi organ tubuh. Perubahan degeneratif yang terjadi pada lansia juga dibarengi oleh munculnya sindroma geriatri yang menyebabkan angka ketergantungan lansia semakin tinggi.

Yuniarti

menyebutkan bahwa lansia selalu beresiko terhadap malnutrisi karena adanya proses penurunan asupan makanan akibat perubahan fungsi usus, inefektifitas metabolisme, kegagalan homeostasis dan defek nutrien. Semakin tua usia seseorang maka resiko seorang individu untuk mengalami malnutrisi akan semakin tinggi. Apabila hal ini tidak tertangani dengan baik dapat menyebabkan defisiensi energi protein dan nutrisi lainnya. Lebih lanjut Chien dan Guo (2014) menyebutkan bahwa malnutrisi pada lansia dapat menyebabkan kejadian gangguan kerja otot, penurunan fungsi kognitif, penurunan massa tulang dan meningkatkan angka kematian.

Gangguan kerja otot dan penurunan massa tulang diketahui akan menggangu kemampuan motorik lansia yang selanjutnya sangat mempengaruhi keseimbangan postural lansia. Keseimbangan postural merupakan salah satu faktor penting yang dibutuhkan seseorang agar dapat melaksanakan aktifitas fungsional. Selain itu keseimbangan postural juga diketahui merupakan salah satu prediktor kejadian jatuh pada lansia.

Jatuh pada lansia merupakan salah satu sindroma geriatrik yang paling banyak menyita perhatian. Hamid et al (2017) menyebutkan bahwa resiko jatuh pada lansia akan semakin meningkat seiring dengan pertambahan usia. Kejadian jatuh pada lansia setiap tahunnya tercatat sekitar $30 \%$ terjadi pada lansia berusia 65 tahun atau lebih dan pada lansia berusia 80 tahun atau lebih angka kejadian jatuh meningkat menjadi $50 \%$ di seluruh dunia. Kejadian jatuh dapat membawa dampak serius yang dapat meningkatkan angka morbiditas dan mortalitas pada lansia karena pada tahapan lansia seorang individu akan beresiko mengalami osteoporosis dan bila terjadi jatuh maka resiko terjadinya fraktur akan semakin tinggi.

Studi pendahuluan yang dilakukan oleh peneliti terhadap 10 lansia di UPT PSTW Jember ditemukan 5 beresiko malnutrisi dan 6 lansia yang membutuhkan waktu lebih dari 13 detik dalam menyelesaikan Timed Up and Go Test yang berarti lansia tersebut beresiko untuk jatuh. Dari studi pendahuluan tersebut peneliti tertarik 
untuk mencari korelasi antara status nutrisi lansia dan resiko jatuh pada lansia. Tujuan penelitian ini adalah untuk mengetahui hubungan antara status nutrisi dengan resiko jatuh pada lansia.

\section{METODE PENELITIAN}

Penelitian ini adalah penelitian korelasional dengan pendekatan cross sectional yang melibatkan 77 responden yang terpilih melalui purposive sampling dari 140 lansia binaan di UPT PSTW Jember. Data pada penelitian ini dikumpulkan dengan menggunakan MNA dan TUG yang kemudian dianalisis dengan mengginakan uji korelasi spearman.

\section{HASIL PENELITIAN}

Karakteristik lansia yang menjadi responden pada penelitian ini adalah sebagai berikut :

Tabel 1 Karakteristik Umum Responden Penelitian (Sumber: Data Primer Penelitian, Januari 2019)

\begin{tabular}{|c|c|c|}
\hline Karakteristik & Jumlah & Persentase \\
\hline \multicolumn{3}{|l|}{ Umur (tahun) } \\
\hline $60-69$ & 37 & 48,05 \\
\hline $70-79$ & 27 & 35,04 \\
\hline $80-89$ & 10 & 12,99 \\
\hline $90-99$ & 3 & 3,89 \\
\hline \multicolumn{3}{|l|}{ Jenis Kelamin } \\
\hline Perempuan & 35 & 45,45 \\
\hline Laki - laki & 42 & 54,54 \\
\hline \multicolumn{3}{|l|}{ Tingkat Pendidikan } \\
\hline Tidak Sekolah & 28 & 36,36 \\
\hline SD & 37 & 48,05 \\
\hline SMP & 7 & 9,09 \\
\hline SMA & 5 & 6,49 \\
\hline \multicolumn{3}{|l|}{ Agama } \\
\hline Islam & 70 & 90,9 \\
\hline Kristen & 5 & 6,49 \\
\hline Hindu & 2 & 2,61 \\
\hline \multicolumn{3}{|l|}{ Status Pernikahan } \\
\hline Lajang & 5 & 6,5 \\
\hline Cerai hidup & 14 & 18,18 \\
\hline Cerai mati & 58 & 75,32 \\
\hline \multicolumn{3}{|l|}{ Riwayat penyakit } \\
\hline Hipertensi & 50 & 64,94 \\
\hline Gout & 14 & 18,18 \\
\hline Lainnya & 13 & 16,88 \\
\hline \multicolumn{3}{|l|}{ Tajam Penglihatan } \\
\hline Utuh & 28 & 36,64 \\
\hline Turun & 49 & 64,36 \\
\hline
\end{tabular}


Tajam Pendengaran

Utuh 52 67,53

Menurun

Riwayat Jatuh

Ya

40

51,95

Tidak

Indeks Massa Tubuh

$\begin{array}{lcc}\text { Underweight } & 8 & 10,34\end{array}$

Normal

Oerweight

$20 \quad 26,03$

Obesitas

$0 \quad 0$

Kemandirian ADL

Mandiri 68

88,31

Ketergantungan ringan

0

Ketergantungan moderat

9

Ketergantungan total

0

Fungsi Kognitif

Normal

0

11,69

Gangguan kognitif sedang

45

0

Gangguan kognitif berat

Total

31

58,44

31

40,26

$77 \quad 100$

1,3

Berdasarkan data pada tabel 1 dapat diketahui bahwa mayoritas responden yang terlibat dalam penelitian ini berusia $60-69$ tahun, berjenis kelamin laki - laki dengan tingkat pendidikan responden mayoritas adalah SMP, beragama islam, status pernikahan cerai mati, memiliki riwayat penyakit hipertensi, fungsi penglihatan dan pendengaran utuh, memiliki riwayat jatuh, dan indeks massa tubuh.

Tabel 2 Status Nutrisi Lansia (Sumber: Data Primer Penelitian, Januari 2019)

\begin{tabular}{ccc}
\hline Status nutrisi & Jumlah & Persentase \\
\hline Malnutrisi & 4 & 5,2 \\
Resiko malnutrisi & 55 & 71,4 \\
Normal & 18 & 23,4 \\
\hline Total & 77 & 100 \\
\hline
\end{tabular}

Berdasarkan data pada tabel 2 dapat disimpulkan bahwa mayoritas responden beresiko mengalami malnutrisi. 
Tabel 3 RIsiko Jatuh Lansia (Sumber: Data Primer Penelitian, Januari 2019)

\begin{tabular}{lcc}
\hline \multicolumn{1}{c}{ Resiko jatuh } & Jumlah & Persentase \\
\hline Normal & 28 & 36,4 \\
Resiko jatuh & 48 & 62,3 \\
Perlu bantuan dalam mobilisasi & 1 & 1,3 \\
\hline Total & 77 & 100 \\
\hline
\end{tabular}

Berdasarkan data pada tabel 3 dapat dilihat bahwa mayoritas responden beresiko untuk jatuh dengan waktu yang dibutuhkan untuk menyelesaikan TUG adalah $14-24$ detik.

Tabel 4 Hasil Uji Korelasi Spearman antara Status Nutrisi dan Resiko Jatuh Lansia

\begin{tabular}{lc}
\hline \multicolumn{1}{c}{ Parameter } & Jumlah \\
\hline Koefisien korelasi & 0,028 \\
Signifikansi & 0,081 \\
\hline Total & 77 \\
\hline
\end{tabular}

Tabel 4 menunjukkan bahwa korelasi kedua variabel memiliki signifikansi 0,081 yang berarti kedua variabel tidak berkorelasi dan memiliki koefisien korelasi 0,028 yang berarti korelasi kedua variabel sangat lemah.

\section{PEMBAHASAN}

Hasil tabulasi data pada tabel 2 menunjukkan bahwa mayoritas responden beresiko malnutrisi. Leslie dan Hankey (2015) menyebutkan bahwa proses menua selalu diiringi dengan berbagai perubahan yang menyebabkan kebutuhan nutrisi lansia menjadi tidak terpenuhi. Lebih lanjut disebutkan beberapa faktor yang mempengaruhi timbulnya kondisi anoreksia pada lansia diantaranya (1) penurunan pengeluaran energi, (2) perubahan fisik (3) perubahan patologis dan (4) faktor sosial.

Penurunan pengeluaran energi pada lansia diantaranya disebabakan oleh penurunan BMI dan penurunan aktifitas fisik. Dari data penelitian didapatkan data $63,63 \%$ responden memiliki BMI normal dan 88,31\% responden mandiri dalam pemenuhan ADL. Namun demikian hasil pengamatan peneliti menunjukkan bahwa selain aktifitas terjadual yang telah disusun oleh pengelola PSTW, lansia banyak memiliki waktu luang yang diisi dengan bercengkerama atau sekedar duduk - duduk. Hal ini menunjukkan bahwa responden mengalami penurunan aktifitas. Sesuai dengan pendapat Leslie dan Hankey (2015) yang menyebutkan bahwa penurunan aktifitas fisik berkontribusi terhadap penurunan laju pengeluaran energi yang berdampak pada jumlah makanan yang dikonsumsi dimana lansia akan cenderung mengurangi intake makanannya sehingga menyebabkan penurunan intake mikronutrien. Pendapat ini didukung oleh fakta dimana beberapa responden mengatakan bahwa terkadang responden tidak menghabiskan satu porsi jatah makannya karena merasa kenyang sehingga mereka akan 
memakan setengah porsi saja dan sisanya akan dimakan beberapa jam kemudian atau saat jam makan berikutnya.ang berpengaruh terhadap munculnya kondisi anoreksia pada lansia.

Dari faktor fisik beberapa hal yang mempengaruhi munculnya anoreksia adalah hormonal, kadar sitokin, penurunan sensasi pengecap dan atau penghidu, dan perubahan organ pencernaan. Dari hal - hal tersebut yang peneliti amati muncul pada responden adalah perubahan organ pencernaan lansia dimana mayoritas responden sudah tidak memiliki gigi geligi yang lengkap. Hal ini akan menyusahkan lansia dalam proses pencernaan makanan. Selain itu kondisi patologis lansia sedikit banyak mempengaruhi kondisi anoreksia. Berdasarkan hasil penelitian sebanyak $16,88 \%$ responden menderita penyakit seperti asma dan TBC yang mana kondisi ini dapat mempengaruhi status nutrisi lansia karena dapat menyebabkan penurunan nafsu makan dan kemampuan menelan makana yang berdampak pada penurunan intake makanan.

Faktor sosial psikologis juga berpengaruh terhadap status nutrisi lansia. Faktor - faktor seperti kehilangan dan terpisah dari orang terdekat akan sangat berdampak terhadap intake makanan lansia. berdasarkan pengamatan peneliti mayoritas responden hidup terpisah dari keluarganya dan seluruh responden terpisah dari pasangannya, terlihat dari status persnikahan responden yang berstatus cerai mati, cerai hidup, dan lajang. Tidak adanya support person dapat menyebabkan lansia merasa malas dan bosan untuk makan.
Berdasarkan data pada tabel 3 diketahui bahwa mayoritas responden beresiko jatuh. Rubenstein dan Josephson (2006) menyebutkan bahwa kejadian jatuh pada lansia dipengaruhi oleh faktor resiko yang terbagi menjadi faktor resiko intrinsik dan ekstrinsik. Faktor resiko intrinsik meliputi (1) gaya berjalan, (2) neuropati perifer, (3) disfungsi vestibular, (4) kelemahan otot, (4) gangguan penglihatan (5) kondisi patologis, (6) peningkatan usia, (7) gangguan pemenuhan ADL, (8) hipotensi orthostatis, (8) demensia, dan (9) obat. Sedangkan faktor ekstrinsik terdiri dari (1) faktor lingkungan , (2) penggunaan alas kaki yang kurang tepat, dan (3) penggunaan restrain. Dari berbagai faktor tersebut beberapa hal yang peneliti amati terdapat pada lansia yang menimbulkan resiko jatuh adalah sebagai berikut.

Hasil pemeriksaan fisik pada responden didapatkan data adanya penurunan fungsi sensori pada lansia ditandai dengan $63,64 \%$ responden mengalami penurunan fungsi penglihatan. Fungsi penglihatan sangat berpengaruh terhadap fungsi keseimbangan karena penglihatan menghasilkan input sensori yang diperlukan dalam proses mempertahankan keseimbangan. Sebanyak 64,94\% responden memiliki riwayat hipertensi dan responden mengungkapkan jika sering mngeluh pusing. Keluhan pusing mengindikasikan adanya gangguan pada proses input dan pengolahan sensori di cerebellum sehingga mempengaruhi kerja sistem vestibularis dalam mempertahankan keseimbangan. Dilihat dari fungsi kognitif responden dapat diketahui bahwa ditemukan 40,26\% responden yang memiliki gangguan kognitif 
sedang. Gangguan fungsi kognitif akan berpengaruh terhadap kemampuan pengambilan keputusan dalam mengkoordinasikan gerak lansia sehingga resiko jatuh pun meningkat. Berdasar tabel 5.1 sebanyak $51,95 \%$ responden memiliki riwayat jatuh. Lansia dengan riwayat jatuh umumnya akan beresiko mengalami jatuh berulang karena jatuh akan menimbulkan trauma tersendiri bagi lansia sehingga lansia merasa takut.

Selain faktor intrinsik, faktor ekstrinsik seperti (1) faktor lingkungan , (2) penggunaan alas kaki yang kurang tepat, dan (3) penggunaan restrain juga berperan dalam meningkatkan resiko jatuh lansia. dari pengamatan peneliti, jarak antar wisma di PSTW relatif jauh, dengan kamar mandi di luar kamar, jalan penghubung berbatu. Kondisi ini dapat meningkatkan resiko jatuh pada lansia. Dari hasil wawancara yang dilakukan oleh peneliti pada beberapa responden, beberapa responden mengatakan pernah memiliki riwayat jatuh terpeleset saat berjalan karena kondisi tanah licin setelah hujan.

Data pada tabel 4 menunjukkan nilai signifikansi korelasi dua variabel adalah 0,081 yang berarti antara status nutrisi lansia dengan resiko jatuh pada lansia tidak berkorelasi signifikan. Berbeda dengan penelitian Chien dan Guo (2014) yang menyebutkan bahwa malnutrisi pada lansia dapat menyebabkan kejadian gangguan kerja otot, penurunan fungsi kognitif, penurunan massa tulang dan meningkatkan angka kematian serta penelitian Leslie dan Hankey (2015) yang menyebutkan bahwa kondisi anoreksia pada lansia dapat menimbulkan kelemahan otot yang berdampak pada keseimbangan lansia.

Tidak adanya korelasi antar dua variabel bisa jadi disebabkan karena timbulnya resiko jatuh pada responden lebih banyak berhubungan dengan faktor intrinsik responden dan faktor eksternal lingkungan. Faktor intrisnsik diantaranya riwayat jatuh, penurunan fungsi kognitif, fungsi penglihatan, kondisi patologis (hipertensi dan gout) dan riwayat jatuh. Sedangkan faktor eksternal lebih banyak berhubungan dengan lingkungan.

\section{SIMPULAN}

Berdasarkan uraian yang telah disampaikan maka dapat disimpulkan bahwa:

1. Mayoritas responden di UPT PSTW Jember beresiko mengalami malnutrisi

2. Mayoritas responden di UPT PSTW Jember beresiko jatuh

3. Status nutrisi dan reiko jatuh pada lansia di UPT PSTW Jember tidak berkolerasi signifian dengan koefisine korelasi rendah artinya korelasi keduanya rendah.

\section{SARAN}

1. Lansia binaan UPT PSTW Jember diharapkan mampu menjaga kemandirian dalam ADL dan mempertahankan kondisi keseimbangannya

2. UPT PSTW harus memodifikasi program pembinaan lansia supaya lansia tidak bosan dan bersemangat dalam menjaga kemandiriannya serta tidak merasa kesepian dan terbuang.

3. UPT PSTW harus dapat memodifikasi lingkungan seperti memasang paving dan 
meningkatkan penerangan sehingga meningkatkan keamanan lansia.

\section{DAFTAR PUSTAKA}

Anak, D. B. G. d. K. I., 2011. Buku Pedoman Pelayanan Gizi Lanjut Usia. 1 penyunt. Jakarta: Kementrian Kesehatan RI.

Eto, F., 2011. Causes Fall In Elderly. Medical Care for The Elderly , 7(44), pp. 299 305.

Hamed, A., Mohammed, N. \& Aly, H., 2017. Elderly Fall Preva;ence and Associated Factors in Sohag Governorate. The Egyptian Journal of Community Medicine, 35(4), pp. 1 - 13.

Krishnaswamy, B. \& Usha, G., 2012. Falls in Older People, Chennai City: Madras Medical College and Goverment General Hospital.

Leslie, W. \& Hankey, C., 2015. Aging, Nutritional Status and Aging. Healthcare Jounal, 3(3), pp. 648 - 658.

MIng, H. C. \& How, R. G., 2014. Nutritional status and Falls in Community Dwelling Old People : A Longitudinal Study of A Population Based. Plos One, 9(3), pp. 1 - 10.

Nacimentos, J. et al., 2013. Association between
Underweight and Overweight / Obesity with Oral Health Among Independently living Brazilian Elderly. Nutrition , III(29), pp. 152 - 157.

Posner, B., Jette, A., KW, S. \& Miller, D., 2013. Nutrition and Health Risk in The Elderly : The Nutrition Screening Initiative. American Journal of Public Health, 7(83), pp. 972 - 979.

Tsai, A., TL, C. \& JY, W., 2013. Short Form MIni Nutritional Asessment with Either BMI or Calf Circumference is Effective in Rating The Nutritional Status of Elderly Taiwanese : A National Cohort Study. British Journal of Nutrition , III(110), pp. 1126 - 1132.

Y, S. et al., 2016. Association Between Functional Capacity Decline and Nuritional Status Based on The Nutrition Screening Initaitive Checklist : A 2 Year Cohort Study of Japanese Community Dwelling Elderly. PLOS one, 11(11), pp. 1 - 10.

Yuniarti, A., Said, S. \& A, S., 2011. Nutritional Status Related To Quality of LIfe of Elderly People in Rappokaling Makassar, Makassar: Universitas Hasanudin. 